\title{
HISTORY OF MAHASKA COUNTY BAR
}

\author{
BY LEROY E. CORLETT
}

In presenting this historical sketch of the Mahaska County Bar, attention is directed briefly to some of the early history of the county. It was named for the noted chief of the Iowa Indians, Ma-has-kah, which signified "White Cloud." Originally the area comprising the county was a part of De Moine county.

The first dwelling was built in the county in 1842 by one MacBeth, upon a claim one mile above the "Hardfish" Indian village, which then occupied the site of Eddyville. He built with the permission and consent of the Indians, who still were in possession of the land.

The county was not opened to white settlers until May 1,1843 , when the land was delivered into the hands of the government by the Indians. Scores of families were camped near the line in April, and, when the last night of the month came, rushed across the border to make choice of claims.

Thereafter development was rapid. The soil was fertile; coal, water, wild game and timber were plentiful; and settlers came in rapidly. The first mill in the county was built on Muchekinock creek by Joseph $\mathrm{H}$. and John K. Bennett in 1843; J. P. Eddy established a ferry at present site of Eddyville in 1844; Miss Semira Hobbs taught the first school in 1844; and a church was organized the same year by the Methodists at Six Mile Prairie. On February 5, 1844, the territorial legislature made provision for the organization of the county. Under that act, William Edmundson was appointed sheriff and M. T. Williams, clerk. Under the territorial law it was the duty of these men to complete the organization of the county. This was carried on as rapidly as developments would permit. Townships were organized, with officers to handle necessary duties.

A dispute arose about the name and location of the county seat. After due consideration, and on May 11, 
1844, the appointed commissioners-Jesse Williams, Thomas Henderson and Ebenezer Perkins-met and finally determined the name for the county seat of Mahaska county to be Oskaloosa, and the location to be the same as the present site.

\section{COURT First Held July 17, 1844}

The commissioners' court first met in Mahaska county on May 14, 1844. The first term of the regular court was held in Mahaska county in 1844, by Joseph Williams of Muscatine, judge in the Second district. There was very little business for the court, but it remained in session for several days. Court was held in an unfinished log house in the present limits of Oskaloosa. The building had no floors. Loose planks were thrown upon cross pieces, furnishing a rostrum for the judge and clerk. A plank laid on two flour barrels supplied a desk for the court.

In this setting, the first court opened and transacted legal business, July 17, 1844. Mahaska county's first courthouse was a two-story building built during the winter of 1844 and 1845 , at the northwest corner of the square. A county jail of log construction was built on North A street in 1845.

The first marriage license was issued in Mahaska county on May 30,1844. The marriage solemnized thereunder was on the second day of June, 1844, in the home of Alexander May, joining in matrimony Samuel C. Nicholson, age twenty-five years, and Miss Eleanor May, nineteen years of age, both of Mahaska county. They were married by Levi Bainbridge, justice of the peace. Let us assume that these young people lived happily ever after.

The pioneers who came to Mahaska county were people of industry and character, who sought the best of educational and religious advantages. Their determination in these particular lines developed in the county the sterling qualities that have made Mahaska county one of the leading and most progressive counties in the state 
of Iowa. In these surroundings grew and developed the pioneer lawyers who established and maintained the Mahaska County Bar on such high professional and ethical standards that they have been characteristic of the bar through all these many years. They left an imperishable record of achievement. These pioneer lawyers are entitled to much praise for work done in making Mahaska county so proud, progressive, and prosperous.

\section{MEMBERS OF THE BAR}

In this sketch of the Mahaska County Bar, the names are alphabetically arranged. Section I refers to the lawyers now deceased, or those who have moved away from Mahaska county. Section II refers to the lawyers who are still practicing law in Mahaska county, August 1, 1948.

\section{. SEĊiION I}

George H. BAUGH was born January 22, 1838, in Highland county, Ohio. At the age of eleven, he came to Mahaska county, where he attended the public schools and later studied law. In 1862, he began the practice of law in Mahaska county, which he continued for four years. In 1870, he was elected mayor of Oskaloosa, and was re-elected for six successive terms.

ROBERT F. BENNETT came to Oskaloosa about 1931 and practiced law there for ten years. In 1941, he left Mahaska county and went to South Bend, Indiana, where he has since lived.

Judge LuCien C. BLANCHARd was born April 15, 1838, in Lewis county, New York. In 1860, he came to Iowa. While teaching school, he read law. This program was interrupted by the Rebellion. He enlisted as a private in Company $\mathrm{K}$ of the 28th regiment of the Iowa infantry, and took part in some of the important engagements of the Civil war. He later graduated from the University of Michigan at Ann Arbor, and began the practice of law in Iowa. In 1868, he was elected judge of the Sixth Judicial district, which district included Mahaska county. After retiring from the bench in about 1874, he continued the practice of law at Oskaloosa until his death on March 1, 1.908. For a time prior to 1885 , J. C. Williams was associated with Judge Blanchard; and thereafter, B. W. Preston. Judge Blanchard was elected to the house of representatives from Mahaska county in 1893, and served one term, after which he was elected to the senate in 1895, and served two terms. He was an excellent lawyer and appeared in important litigation. He was very much interested in the Masonic 
fraternity, of which he was an active and influential member; and at the time of his death, he was a member of the G. A. $R$. Judge Blanchard was able, honest, efficient, and the type of lawyer who was an honor to his profession.

JAMES B. BoLToN interrupted his education by enlisting in the Third regiment, Ohio infantry, during the Civil war. Owing to ill health, he was returned to his Ohio home. He came to Mahaska county on March 16, 1863, where he studied and was admitted to the bar in 1865 . He was born at Mount Vernon, Ohio, December 26, 1840, and died about twelve years ago. He was an active lawyer, interested in affairs generally, and was the senior member of the firm of Bolton \& McCoy.

L. C. BoLton was the son of James B. Bolton, and born in Mahaska county. He acquired his education in the public schools, read law in his father's office, and was admitted to the bar of Iowa. He was associated with his father in the practice of law in Oskaloosa for a number of years. He then went west and continued the practice of law, but we know nothing further of his later history.

CoL. P. GAD BRYAN was one of the early lawyers of Warren county, Iowa. In later years, he was associated with his son-inlaw, George W. Seevers, in the practice of law in Mahaska county for a time, but his home and regular place of practice was Warren county. In politics, he was a Democrat. He served as a colonel in the Civil war. Mr. Bryan was born December 11, 1825, and died at Des Moines, Iowa, March 22, 1910. He was a cousin of William Jennings Bryan.

WALTER C. BURRerL was a member of the firm of Burrell \& Devitt, and located in Mahaska county about 1897. The firm was successfully engaged in a general practice of law in Mahaska county until the death of Mr. Burrell, December 8, 1921.

JAMES CARRoLL was admitted to the bar of Iowa and located at Oskaloosa in Mahaska county, where he began the practice of his profession. He was elected and served as county attorney, from the beginning of 1895 until 1898. He died about 1900.

A. M. CASSIDAY, a young attorney who located in Mahaska county, attracted the attention of the voters, and was elected as prosecuting attorney from 1851 to 1855 . We have been unable to find further information concerning Mr. Cassiday.

W. W. Chapman came to Mahaska county in 1846 as a young lawyer, remained only a short time, and in 1847 moved to Portland, Oregon. The trip was made across the plains with ox teams. There our trail ends. 
C. P. Cone, a member of the firm of Cone Brothers, was born in Mahaska county, March 27,1845, and was admitted to the bar in 1876. He was associated with his brother, W. J. Cone, who also was born in Mahaska county, on August 5, 1848, and was admitted to the bar in 1874. The firm of Cone Brothers practiced law in Mahaska and Monroe counties for a number of years. We do not have access to further history of these brothers. It is evident that they are long since deceased.

JUDGE J. A. L. CROoKhAM, a pioneer lawyer, banker, and statesman, was born in Jackson county, Ohio, where he remained until he was nearly twenty-one years of age. His progressive ambition took him into activities which finally brought him to Oskaloosa, Mahaska county, in 1845. From his birthplace, he traveled most of the trip on horseback. He was soon admitted to the bar of Iowa, and began practice in Lee county. In 1847 , he returned to Oskaloosa, where he remained until his death on May 2, 1901, at the age of 83 years, 6 months, and 3 days. Judge Crookham was an able pioneer in all lines, and had much to do with the progressive upbuilding of the community. He was the first judge in Mahaska county, and served as such from August, 1851, to August, 1855. He had agricultural interests, which he pursued with success, along with his legal practice. His labors were extensive and successful. As lawyer and judge, he was an able leader.

SEN. M. E. CuTTS, born in Orwell, Addison county, Vermont, May 22, 1833, died in Mahaska county on September 1, 1883 . He attended Lawrence Academy in Potsdam, New York, after which he joined a surveying expedition. In 1853 , he went to Sheboygan, Wisconsin, where he taught school and read law for two years. In June, 1855, he came to Iowa, and was admitted to the bar in August, 1855, and located at Montezuma, Poweshiek county. There he practiced his profession until August, 1866, when he came to Oskaloosa. He was elected to the state legislature in May, 1861, and to the state senate in 1863 , where he served four years. He was appointed attorney general of the state in 1872, and was later elected and held that office until January, 1877. He was elected to congress in 1882 . Mr. Cutts made his way by application to work and study, untiring energy, and perseverance. $\mathrm{He}$ attained the respect of his fellow citizens, and deservedly - reached a very high position in his profession.

Francis M. DavenPort, born May 1, 1840, in Gallia count, Ohio, settled in Oskaloosa October 5,1847 . He received his law training at the Michigan university at Ann Arbor, Michigan. For a time, he was associated with the firm of Severs \& Cutts in Oskaloosa, and then engaged in an extensive legal practice by himself. $\mathrm{He}$ was interested in agricultural and mining operations. In 
politics, he was a Jacksonian Democrat, always interested in the welfare of his chosen party. Mr. Davenport is long since deceased.

David S. DAvid was born at Prescott, Iowa, December 29, 1879. He obtained his education at Drake University, was admitted to the Iowa bar in 1904, and immediately began practice in Mahaska county. For a time prior to his death on March 22, 1944, there were associated with him in the practice of law his son, Virgil David, and his son-in-law, Earl R. Jones. Politically, Mr. David was a Republican. He served on the city council of Oskaloosa, 1925-1926, and was city solicitor of Oskaloosa, 1926-1930. He was a member of the $K$. of $P$. lodge. In addition to his legal practice, he was interested in farming.

VIRGIL DAvid was born at Oskaloosa Iowa, in 1907. He attended the University of Iowa and the Drake university law school, and was admitted to the bar of Iowa on June 8, 1933. In September of that year, he came to Oskaloosa and began the practice of law with the firm, David, Jones \& David, his father being the senior member of the firm. He was a Republican in politics, and a member of the Phi Gamma Delta fraternity. He was very much interested in outdoor sports, particularly hunting, fishing, and baseball. He was a member of the Cincinnati Reds national league baseball team. He was also captain of the basketball and baseball teams at the University of Iowa. He was a fine young man. Death took him on February 16, 1934. His sudden death ter: minated a very promising career.

DANIEL W. DAvis, member of the firm of Carroll \& Davis, was born in Monroe county, Iowa, August 24, 1858, and became a resident of Mahaska county at the age of seven years. He was educated in the Beacon schools and later attended Oskaloosa college. When twenty-one years of age, he entered the law office of F. M. Davenport, where he studied law, and was admitted to the Iowa bar December 16, 1882. In 1886, Mr. Davis was elected city solicitor. Politically, he was a Democrat. The firm of Carroll \& Davis continued their practice for some years. Mr. Davis died February 19, 1939, at Oskaloosa.

JAMES ARTHUR DEviTT, a member of the firm of Burrell \& Devitt, was born June 1, 1872. He graduated from the law department of the State University of Iowa in 1897, and began practice in Oskaloosa soon thereafter. Mr. Devitt served as county attorney in Mahaska county for two terms. He died at Oskaloosa June 30, 1939. Mr. Devitt was active in the affairs of the fraternal organizations, such as the Elks and Masons. He enjoyed a fine legal practice, which took him into numerous fields of professional activity. He was a Republican in politics, and very prominent in the activities of his party. He was justly rated as a very good 
lawyer, and as one of the best at the Mahaska county bar. Mr. Devitt once served as president of the Iowa state bar association.

Dwight F. Downing was born November 15, 1854, in Ohio. After receiving his preliminary education, he took a law course, and was admitted to practice law in the state of Iowa. He embarked upon his profession in Mahaska county, where he continued with the work of his profession until his death at Oskaloosa on January 22, 1909.

OLIVER N. Downs was born at Logan county, Ohio, May 6, 1861, and came to Mahaska county the following year. In 1881, he attended the Michigan law school at Ann Arbor, from which he graduated in 1883 . In about 1885 , he began the practice of law in Mahaska county. In polities, Mr. Downs was a Republican. He was also a member of the $K$. of $P$. lodge. He died at Oskaloosa, Iowa, June 5, 1916.

ENOCH W. EASTMAN was born in New Hampshire in 1810. He worked on his father's farm, and later in a saw mill. He acquired an academic education, and when twenty-five years of age studied law and was admitted to the bar. In 1844, he moved to Burlington, Iowa. He located in Oskaloosa in 1847, where he successfully practiced law for ten years. He then moved to Eldora, Iowa, where he lived until his death. He was a Democrat in his earlier political activities, but later joined the Republican party. He was a Mason and a Unitarian. During the Tenth General Assembly of Iowa, while Mr. Eastman was lieutenant-governor, he presided over the senate. While practicing law in Oskaloosa, he was for a time a partner of Samuel A. Rice. In the early movement to form Iowa as a state, Mr. Eastman was one of the young men who prevented the separation of the Missouri valley from southern Iowa. He helped incorporate the city of Oskaloosa, and served on the city council. His ability gained him state-wide recognition during the time he served as lieutenant-governor, beginning in 1864. Mr. Eastman contributed this sentiment for the Iowa stone contributed by Iowa to the Washington monument: "Iowa-Her affections, like the rivers of her borders, flow to an inseparable Union."

JoHN CLARENCE EICHHORN was admitted to the bar of Iowa in 1918, and began practice in Oskaloosa in 1920. He was associated with the firm of Devitt \& Eichhorn until 1942, then with the firm of Eichhorn \& Gilbert from 1942 until 1946. His death occurred in Oskaloosa December 24, 1946. Mr. Eichhorn was born at Remsen, Iowa, September 21, 1895, and received his education at Colorado college, Occidental college, and the University of Iowa law school. In politics, he was a Republican. During World War I he served as a corporal in the United States army from 1918 to 1919. Out- 
side of his profession, he served as director and president of the chamber of commerce, member of the city plan commission, and county chairman of civilian defense. Mr. Eichhorn was a member of the American Legion, the Elks, and Masons. From 1939 of 1940, he was first assistant attorney general of the state of Iowa. Mr. Eichhorn was a careful, thorough, and dependable lawyer. His early death was a distinct loss to the Mahaska county bar.

Frank E. Gordon came to Mahaska county for the practice of law in about 1904. He was associated with the firm of Shangle \& Gordon. After practicing in Mahaska county for about twentyfive years, he went west, and died about 1947.

Horace W. Gleason, for a time a member of the firm of Crookham \& Gleason, was born in Warren, Grafton county, New Hampshire, May 2, 1846. Mr. Gleason attended the common schools of his community, and took academic work at Newburg, Vermont, and also studied in the Phillips academy, Andover, Massachusetts, preparatory to his entrance to Dartmouth college. Upon the outbreak of the Civil war, he enlisted in the Twelfth regiment, New Hampshire infantry, Company G. He was in the second battle of Bull Run, Antietam, Fredricksburg, Chancellorsville, Gettysburg, Cold Harber, and many other very important engagements. He was admitted to the bar in Iowa in 1869 , and came to Mahaska county in May, 1872, where he continued the practice of his profession until his death, April 20, 1911. Mr. Gleason was a member of several Masonic bodies and of Phil Kearney Post No. 40, G. A. R. In politics, he was a Republican. In 1878, he was elected state representative, and ably represented his constituents.

WILliam P. Hellings was born in Logan county, Ohio, May 29,1851 . At the age of two years, he came with his parents to Mahaska county, and attended the schools there. Later, he joined the United States government survey, with which he worked for two years. He learned the printing trade and worked in a printing office for five years, during which time he also was correspondent for several eastern newspapers. In 1876, he graduated from the law department of the state University of Iowa, and was admitted to practice law in Mahaska county, where he practiced his profession for two years. He then entered the loan and abstract business.

Chardes C. Heningar, one of the leading lawyers of Keokuk county, began his practice in Oskaloosa about 1898. He was in Mahaska county but a short time, and then moved to Sigourney, Iowa, where he enjoys a good legal practice and abstract business. At this time, he is still active in his profession. 
JoHN M. Herron, born at Clermont, Ohio, January 25, 1845. In 1865, he moved to Sterling, Illinois, where he taught school and studied law. He was admitted to the bar of Iowa in 1869 . He practiced for a time in Des Moines. In 1876, he came to Oskaloosa and Mahaska county, where he practiced until the time of his death. With his other activities, he served as justice of the peace in Oskaloosa. He died at Oskaloosa, November 30, 1914.

JoHN A. HOFFMAN came to Oskaloosa in 1861. He attended school at Iowa Wesleyan university at Mount Pleasant, Iowa. He studied law and was admitted to the bar in 1874. After that time, he practiced law in Oskaloosa, Mahaska county. He was a Republican in politics. His interests were embodied in his profession. Mr. Hoffman was born April 23, 1851, in Jackson county, Ohio, and is now deceased.

LEONARD H. HOLE received his preliminary education in Carroll county, Ohio, where he was born June 23, 1845. He graduated from Mount Union College in 1867. He served two years in the Civil war. He studied law in southern Illinois and at the Iowa State University at Iowa City, Iowa. In 1870 , he came to Oskaloosa, where he practiced his profession until his death. He was a Republican, and served as chairman of the county central committee. He also served on the city council of Oskaloosa. Mr. Hole was at one time associated in the practice of law with Howard Hillis, at New Sharon, Iowa.

Charles E. Hutchins was born in Oskaloosa, Mahaska county, Iowa, December 30, 1910. He attended Penn college in Oskaloosa and the University of Illinois. He was admitted to the bar of Iowa in 1936, and on July 1 of that year began practice of his profession in Oskaloosa. He belongs to the Phi Beta Kappa. In politics he is a Democrat, and has been active in the party organization. During World War II, he served in building air bases and hunting for atomic material in the far North. About two years ago, Mr. Hutchins moved to Belle Plain, Iowa, where he is now engaged in the practice of law.

J. KetLY JohnsoN was born in Greene county Ohio, August 22,1841 . At an early age, he moved to Indiana and received his early education in that state and in Ohio. He later entered law school at Ann Arbor, Michigan. Following that, he attended law school at Des Moines, Iowa, and was admitted to the bar in the spring of 1867. He spent one year at Eddyville, Iowa, and then became associated with George W. Lafferty at Oskaloosa. He was city solicitor for Oskaloosa for six years. In 1879, he was elected to the state senate, participating in the activities of the eighteenth and nineteenth General Assemblies, when the constitutional amendment prohibiting the manufacture and sale of 
intoxicating liquor as a beverage was framed and submitted to the people. In the nineteenth General Assembly, he was chairman of the committee on constitutional amendments in the senate. In 1882, he was the Republican candidate for judge of the Sixth Judicial district, was elected, and held that office for twelve years. The fine abilities and absolute fairness of Judge Johnson, under all circumstances, removed all opposition to his election to the bench. He was one of the able, outstanding judges who have served in Mahaska county. He died November 12, 1894.

Sen. William G. Jones was born in Garfield Township, Mahaska county, on the twenty-second of October, 1861, of a pioneer family who come from Wales. He graduated from the high school at Beacon, Iowa, and also from Oskaloosa college in the class of 1882. He entered the law department of the state University of Iowa in 1883, and graduated in 1884. In February, 1885 , he entered upon the practice of his profession at Oskaloosa, Iowa, where he still remains as a member of the bar. He served in both house and senate of Iowa General Assemblies. He has retired from active practice and is now living with his daughter at Sigourney, Iowa. Mr. Jones had many business interests in Mahaska county, beneficial to himself and to his friends.

Cart. William H. Keating was born August 3, 1855 . In the spring of $1863, \mathrm{Mr}$. Keating moved with his parents from the city of his nativity, Boston, Massachusetts, to Poweshiek county, Iowa. After industrious study for a number of years, he acquired a good general education, and entered the law department of Drake university at Des Moines, Iowa, in the spring of 1884 , and graduated therefrom in June, 1885. In May, 1886, he was admitted to practice law in Iowa. In 1890 , he came to Oskaloosa, where he made his home, and where he carried on a very successful abstract and law business until his death on December 9, 1942. At the outbreak of the Spanish-American war, he entered military service as Captain of Company $F$ of the 51st regiment of Iowa infantry, and was in active service for nineteen months, most of which time was in the Philippine Islands. Captain Keating, as he was known by his friends, was public spirited and interested in all movements for the public good. He always had the respect and confidence of his clients.

W. S. Kenworthy lived in Henry county, Indiana, where he was born May 24, 1840, until he was eighteen years of age, when he came to Jasper county, Iowa. He taught school and studied law, and was admitted to the bar in 1865 . He soon located at Oskaloosa, Mahaska county, where he practiced his profession until his death. Mr. Kenworthy was a Republican, and participated many times in political campaigns outside the state of Iowa. He was a fine speaker. 
ROBERT KISSICK located in 'Oskaloosa, Mahaska county, April 7,1859 , when he was sixteen years of age. He was born in Mercer county, Pennsylvania, May 4, 1843. In August, 1862, he enlisted in the $33 \mathrm{rd}$ regiment, Iowa infantry, Company $\mathrm{C}$, and served as a sergeant and U. S. color bearer. In 1864, he was transferred to the 113th U. S. colored infantry, and was commissioned first lieutenant and adjutant. He served through many of the decisive campaigns of the Civil war. He was released because of ill health. Following his military service, he taught school, studied law at the State University of Iowa, and graduated from the law department there in 1872. He then practiced law at Oskaloosa. He was deputy United States revenue collector for Mahaska and Marion counties for three years. Mr. Kissick was very active in Phil Kearney Post No. 40, G. A. R., of Oskaloosa. He was a Republican, and cast his first vote for Abraham Lincoln in 1864. He contributed to the statesmanship of Iowa by his able treatment of public questions. Mr. Kissick was an efficient and highly respected citizen. He continued active until his death.

MAJOR JoHN F. LACEY. In 1861, he was the fifth man in Mahaska county to respond to the president's call for military service, enlisting as a private in Company $\mathrm{H}$, Third Iowa volunteer infantry. During the war, his advancement, based upon merit and ability, was frequent, and resulted in a commission as major. $\mathrm{Ma}$ jor Lacey was born at New Martinsville, West Virginia, May 30, 1841. In 1855, his parents and family moved to Oskaloosa, Mahaska county. Major Lacey, as a boy, attended school at Wheeling, West Virginia, and later at Oskaloosa, Iowa. He studied law with Samuel A. Rice, then attorney general of the state of Iowa. At the close of the war, and after his return to Oskaloosa, he was admitted to the bar, September 16, 1865, and opened a law office in Oskaloosa two days later. He entered a partnership with William E. Shepherd, which continued to 1873 . The firm then became John F. \& William R. Lacey, which continued until Major Lacey's death. He was elected representative to the Thirteenth General Assembly of Iowa from Mahaska county in 1869. In 1879, he was elected city solicitor of Oskaloosa, and the following year was a member of the city council. Major Lacey traveled extensively abroad. In 1888, he was elected to congress and served as such through the 1904 term. He was interested in conservation and preservation of wild life, and has been referred to as the "Father of Conservation." Major Lacey died at Oskaloosa, Iowa, September 29, 1913. His great success as a lawyer and statesman was due to his tireless energy, his integrity, and his honor. Major Lacey was a fine lawyer and able statesman. 
WILLIAM R. LACEY, who was associated with his brother, Major John F. Lacey, for many years in the practice of law in Mahaska county, was born August 13, 1846, at Richmond, Virginia. He was educated at the University of Michigan, Ann Arbor, Michigan, and soon thereafter was admitted to the bar of Iowa and began practice of law at Oskaloosa. In politics, he was a Republican. He was a Mason, Elk, and Eagle, and belonged to the Episcopal church. He and his brother enjoyed a very fine law practice in Oskaloosa until his death, February 14, 1923. John F. and W. R. Lacey were a well-known firm of lawyers in Mahaska county for many years, and their practice reached into all branches of the legal profession.

GeORGE W. Lafferty. In April, 1861, Mr. Lafferty enlisted in the 10th regiment, Pennsylvania reserve volunteer corps, Company $G$, for a service of three years. He served until May 31, 1864 . Following his military service, and on July 16, 1864, he located at Oskaloosa, Mahaska county. He studied law and was admitted to the bar in 1865. He was associated with John R. Needham and also with J. Kelly Johnson. Mr. Lafferty was elected district attorney in the fall of 1874 , which office he held for a number of years. He was born in Mercer county, Pennsylvania, April 9, 1838. Mr. Lafferty was one of the pioneer lawyers. Much of his service was original and of wide public interest and benefit. $\mathrm{He}$ continued practice until his death.

JoHN E. LAKE came to Oskaloosa about 1918, and was for a time associated with Thomas J. Bray in the practice of law. He remained for several years and then moved away, and is reported to have died in the south a few years ago.

Judge William Loughridge. On July 11, 1827, in Youngstown, Mahoning county, Ohio, William Loughbridge was born. He attended the common schools and gained considerable knowledge for the time. He was admitted to the bar of Ohio by the supreme court in 1852. Soon theerafter, he located at Oskaloosa, Mahaska county, Iowa, and engaged in the practice of law. He was elected mayor of Oskaloosa in 1855 and to the state senate in 1856 . In 1861 , he was appointed to fill a vacancy on the district bench in the Sixth Judicial district, and that fall was elected to that office, and later was re-elected and served on the bench until January, 1867. In 1866, he was elected by the Republicans as representative in Congress, from the most populous district in the United States. He was re-elected in 1868, and served to March 4, 1871. He was claimed by death September 26, 1889.

JoHN O. MALCOLM, one of the able and active lawyers of Mahaska county, was born in Ohio, October 16, 1852. He acquired 
a good education, then entered the study of law, was admitted to the bar of Iowa, and soon thereafter began practice of his profession in Oskaloosa, Mahaska county, Iowa, where he enjoyed a fine business up to the time of his death, May 20, 1933. During the years of his practice in Mahaska county, he was associated with Byron V. Seevers, George W. Seevers, and George C. True. Mr. Malcolm was rated as a very good lawyer.

JUDGE BEN MCCOY, a member of the firm of Bolton \& McCoy, one of the pioneer law firms of Mahaska county, was born in Jefferson county, Indiana, May 22, 1846. He came with his parents to Mahaska county in 1855 , and attended the public schools until he reached the age of seventeen years, when he entered Cornell college at Mount Vernon, Iowa, and graduated with honors in the class of 1868. He entered the law office of Seevers \& Cutts in 1871 in Oskaloosa, and the following year was admitted to the bar. In 1872, he moved to Keokuk county, where he began the practice of law as a member of the firm of Andrews \& McCoy. In January, 1874, he returned to Oskaloosa, entered the partnership of Bolton \& McCoy, and practiced his profession in Mahaska county until his death in 1918 . He served as city solicitor of Oskaloosa in 1876. In 1873, he was elected senator from Mahaska county by the Republican party. In 1864, he enlisted in Company $\mathrm{H}, 46$ th Iowa volunteer infantry, and served during the Civil war. $\mathrm{He}$ was a Knight Templar, affiliated with DePayens Commandery No. 6, Oskaloosa. Judge McCoy was the father of John N. and Hugh B. McCoy, later mentioned in this article. Judge McCoy was a successful lawyer, and as such, was elected to the judgeship of the district of which Mahaska county was a part.

H. B. MCCoY was born at Oskaloosa, Iowa, in 1879. He received his education at Iowa Wesleyan college, Mount Pleasant, Iowa, and the State University of Iowa, and was admitted to the bar of Iowa in 1903. Prior to his entering law practice, he served as claim agent for the IM. \& St. L. Railway company. In 1911, he began the practice of law, associated with his brother, John M. McCoy, under the firm name of McCoy \& McCoy. He was a Republican, and for a time served as United States district attorney. He was a member of the B. P. O. E., Masons, and Phi Delta Theta. He died at Oskaloosa, Iowa, August 1, 1940. Mr. McCoy was active in his legal practice and gave particular attention to trial work. The firm of which he was a member was well known and had an extensive practice.

JoHn N. McCoY, a member of the firm of McCoy \& McCoy, and the son of Judge Ben McCoy, was born at Sigourney, Iowa, November 22, 1873, and was admitted to the bar of Iowa in 1897. He received his college training at Cornell college and at Iowa 
university. He began the practice of law in Mahaska county in 1897, being associated with his father, Judge Ben McCoy, and his brother, H. B. McCoy. Politically, he was an active Republican, served as county chairman of that party, and was a delegate to the national convention in 1932. Mr. McCoy was city attorney from 1901 to 1903 and county attorney of Mahaska county, 19051907, and as such he was aggressive and successful. Mr. McCoy was a Mason, an Elk, and a Modern Woodman. He also belonged to the Delta Theta Phi fraternity. Outside interests included hunting, fishing, horses, and dogs. Mr. McCoy served in the Philippine insurrection during the Spanish-American war. He died at Oskaloosa, Iowa, July 25, 1946. During his lifetime, he enjoyed an extensive practice and the confidence of his clients.

JoHN McCuTChen was born at New Sharon, Iowa. $\mathrm{He}$ was admitted to the bar of Mahaska county and practiced law at Oskaloosa about ten years, during which time he was county attorney for four years, beginning in January, 1913. Following that, he moved to California in about 1925, where he practiced law until his death in 1937.

GIDEON B. MCFALL was born at Fremont, Mahaska county, August 3, 1861. He attended the common schools, Oskaloosa college, and the law department of the State University of Iowa, from which he graduated June 19, 1884. He began the practice of law at Oskaloosa in September of the same year, and in 1885 formed a partnership with Sen. William G. Jones, under the firm name of McFall \& Jones. Mr. McFall was a Mason and a Democrat in politics. In 1891, he was elected mayor of the city of Oskaloosa and continued as such until April 2, 1894, when he resigned. He was also interested in education, agriculture, and business, and was active with these interests, as well as his law practice, until his death.

Liston MCMILLEN was born in Richwood, Union county, Ohio, on the tenth day of December, 1847. He studied in the common schools of his home county until fourteen years of age. After that, he entered Ohio Wesleyan University at Delaware, from which he graduated in 1867. On April, 1868, he came to Iowa, and was admitted to the bar in 1869. Immediately thereafter, he located at Oskaloosa in Mahaska county. He was a Republican in politics. He was a writer of some ability on international peace. His legal practice extended into courts outside his home county. A supporter of public improvements and progress, he was a student of sociology, economics, and other public questions, as well as those connected with his profession. Mr. McMillen died a number of years ago. 
GeOrge C. Morgan was a practicing attorney at Oskaloosa, Iowa, as a member of the firm of Lafferty \& Morgan. He was born in Portage county, Ohio, January 31, 1847, a child of Welsh parents. He was educated in Hiram college and Mount Union college, Ohio. In 1870, he began the study of law at Davenport, Iowa, and was admitted to the bar of Iowa in May, 1875, when he moved to Mahaska county, locating at New Sharon. In 1883, he moved to Oskaloosa, and the following year formed a partnership with George W. Lafferty. He was a member of the Christian church and in politics a Republican, and a member of the Masonic fraternity and Knight Templars. He was considered a careful lawyer, devoted to the interests of his clients. He died September $22,1898$.

L. M. MORRIs had been a practicing lawyer in South Dakota for some years prior to coming to Mahaska county in about 1932. He maintained an office and practiced in Oskaloosa for about ten years, until his death. He was associated with Dan W. Davis part of that time.

Frank Tecumseh Nash was born in Mahaska county December 1, 1869. After going to the public schools, he attended Penn Academy, and in 1893 received his B. A. degree from Penn college, Oskaloosa, Iowa. In 1895, he attended the law department of the University of Michigan, and received his LL. B. degree. He was admitted to the Iowa bar and began the practice of law in Oskaloosa in 1897, and so continued until his death at Oskaloosa May 26,1945 . Mr. Nash served for a number of years as trustee of the library board, the Y. M. C. A. board, and on the board of Penn College. In addition to his legal practice, he was interested in agriculture. He was a Democrat, a Mason, a K. of P., and a Presbyterian.

SEN. JoHn R. NeEDHAM as a young man came to Oskaloosa and in 1850 printed the first newspaper. This was the beginning of the Oskaloosa Herald. He was a young lawyer, and was elected to the senate in 1852. During the Civil War, he was lieutenant governor and speaker of the senate. His health failed, and he died a comparatively young man, July 9,1868 .

William Houtz Needham, son of John R. Needham, studied law and was admitted to the bar of Mahaska county, and began his practice. Shortly afterward, however, he was stricken with typhoid fever, and died suddenly.

William R. Nelson was born in Greene county, Pennsylvania, May 7, 1858. He studied at Oskaloosa college and the Iowa State university and settled in Oskaloosa in 1880. He had studied law with F. M. Davenport and with Bolton \& McCoy, and was admitted 
to the bar August 20,1882, and immediately started on the practice of his profession in Oskaloosa. November 16, 1885, he formed a partnership with J. C. Williams, which lasted for some time. Mr. Nelson's activities took him into a varied practice, which was considered successful. He left Oskaloosa over twenty years ago.

Gen. MaXwell A. O'Brien, born in Chicago, Illinois, November 21, 1890, came to Oskaloosa, Mahaska county, Iowa, in about 1900. After completing grade and high school he attended Penn college. He graduated from the law college of the State University of Iowa in 1914, and immediately began the practice of law in Oskaloosa as a member of the firm of Lacey \& O'Brien.

$\mathrm{He}$ was elected county attorney on the Republican ticket and served three terms, which service was interrupted by World War $I$, in which he served in the field artillery. As county attorney he made an excellent record. In $1922 \mathrm{Mr}$. O'Brien was appointed assistant attorney general of Iowa, and placed in charge of the criminal appellate work. In 1924 he was appointed first assistant attorney general of Iowa and was placed in charge of the state banking department. In 1928 he was appointed counsel for the state highway commission and served as such until 1932, when he resigned and became a member of the law firm of Parrish, Guthrie, Colflesh, and O'Brien in Des Moines, Iowa, where he is still active and successful in his profession.

He maintained his interests in military activities after World War I, and promoted the organization of two cavalry troops in Oskaloosa, as a part of the Iowa national guard, and on January 13,1941 he was inducted as commanding officer of the 113th cavalry, which was sent to Brownwood, Texas. He commanded the regiment until January 1942, when he was promoted to Brigadier general in the U. S. army, and assigned as assistant division commander of the 4 th motorized division at Augusta, Georgia. In 1943 he was given command of the U. S. troops of several Aleutian islands including Kiska, Amchilka, Shimea, and Umnak, where he served until the end of World War II, when he retired from active duty.

Mr. O'Brien is a Mason, Shriner, member of the Des Moines club and a progressive, public-spirited citizen.

Charles C. Orvis was born in Henry county, Illinois, October 10, 1869. He attended the public schools in Illinois and Wisconsin, and graduated from the law department of Valparaiso university at Valparaiso, Indiana, in 1893 , with a B. L. degree. In 1894, he came to Oskaloosa, where he practiced law until his death. Mr. Orvis was a city solicitor for Oskaloosa, 1904-1910. He was a Republican and a member of the Mahaska county and state bar 
associations, and was a Modern Woodman and an Eagle. He was also a member of the Episcopal church.

M. T. Peters was a young lawyer who practiced in Oskaloosa long ago, and was described as an industrious and smart attorney. He went to California during the gold rush.

A. G. PHILLIPS, who came early to Mahaska county, was a Whig, and in the summer of 1846, was a candidate on that ticket for judge of the probate court, but was defeated by John White. In 1852, Mr. Phillips went to California, where he remained until his death.

O. C. G. Phir..IPs was born in Oskaloosa August 31, 1848. He received his education in Ohio Wesleyan university at Delaware, Ohio, then studied law in the office of Judge Crookham in Oskaloosa, and was admitted to the Iowa bar in 1872 . He practiced his profession in Mahaska county until the time of his death. Mr. Phillips was a unique character. Known by many in the county outside of the bar, he was friendly and maintained to the time of his death the friendship of those who knew him best. In his later years, he served as justice of the peace in Oskaloosa. He died at Oskaloosa December 27, 1923.

Blanchard W. Preston, son of Judge Byron W. Preston, was born September 23, 1892. He received his education in the Oskaloosa public schools, State University of Iowa, and the law departments of Northwestern university and Drake university. He was admitted to the Iowa bar in October, 1917, and practiced law at different places. He was in World War I in a special detached service. In 1925, he started practice with his father in Oskaloosa, under the firm name of Preston \& Preston. In 1925, he was elected prosecuting attorney for Mahaska county on the Republican ticket, and was re-elected in 1928. He was a member of the Mahaska and Iowa Bar Associations, American Legion, Masons, K. of P., Beta Theta Pi fraternity, and the Episcopal church. He later moved to California.

Judge Byron W. Preston, a leading member of the Mahaska county bar, was born in Newton, Iowa, February 13, 1858, and died at Oskaloosa, Iowa, January 18, 1939. Judge Preston received his education in the public schools and at Grinnell college. On June 31,1883 , he came to Oskaloosa and began the study of law with Judge L. C. Blanchard. In March, 1884, he was admitted to practice law at the bar of Mahaska county and later became a partner of Judge Blanchard. He was county attorney for two terms and city attorney for Oskaloosa in 1899 and 1900 . In 1902 , as a member of the Republican party, he was elected judge of the district court and took office as such on January 1, 1903 , in which position he served nine years. In 1911, he was 
elected to the supreme court of Iowa, and served as supreme judge until 1925. After his retirement from the supreme bench, he came back to Oskaloosa and practiced law until his death. During his practice, Judge Preston handled many important cases: He was always considered as one of the strongest and best judges in the state of Iowa. He was associated with a number of fraternal organizations, and enjoyed the association of the members thereof. He was a vestryman of the Episcopal church at Oskaloosa.

Fred A. Preston, born at Grinnell, Iowa, in 1872. After attending the public schools in his home district, he attended Grinnell college. He came to Oskaloosa in 1898 and entered the law office of his brother, Judge Byron W. Preston, where he remained until June of the same year. He then enlisted in Company F, 51st Iowa infantry, at Des Moines, and served in the Spanish-American war. His organization arrived in Manila harbor on the seventh of December of that year. He returned to Mahaska county on November 7, 1899. In the spring of 1900 , he entered the law department of the State University of Iowa, and graduated in June 1901, and was admitted to the bar. He returned to Oskaloosa and continued practice with his brother. After his brother, Byron W. Preston, was elected to the bench, Fred formed a partnership with Mr. Gleason. The firm was Gleason \& Preston, and continued for a number of years. Mr. Preston was a Republican in politics. Some years ago, he moved to California, and engaged in business there. Since then, we have no further details of his activities.

EdWard Pritchett, born February 6, 1874, at Tuscaloosa, Alabama. His preliminary education was acquired at Fort Madison, Iowa. He later attended the State University of Iowa and the Iowa Collegiate school. He graduated from the law department of the State University of Iowa in June, 1899. In 1901, he moved to Oskaloosa and engaged in the practice of law there. For a time he was associated with J. G. Patterson. June 20, 1904, he was appointed to the office of justice of the peace. He was a Republican in politics, a Mason, an Elk, and a Modern Woodman. In the Spanish-American war, he served in Company $F$ of the 50th Iowa volunteer infantry. He was one of the first to volunteer in that company, and was mustered out November 30,1898 . A few years later, he moved away from Mahaska county, and later information concerning him is lacking.

Frank D. ReID was born in Indiana county, Pennsylvania, September 10, 1850. He graduated from Oskaloosa college in 1874, and entered the law department of the State University of Iowa, from which he graduated in 1879. He was admitted to the 
bar in that year and began his practice in Oskaloosa, where he continued in the law and abstract business to the time of his death in Oskaloosa on August 27, 1928.

Sylvester V. Reynolds was born in Poweshiek county, Iowa, on the twenty-first day of July, 1867. Mr. Reynolds attended the public schools, spent one year at Oskaloosa college and one year at Penn college, Oskaloosa. He taught school in Mahaska county for thirty-three terms. He attended the Iowa college of law at Drake university, Des Moines, from which he graduated on May 17, 1899. He located in New Sharon in Mahaska county on June 6,1899 , where he practiced law in connection with other business activities for a number of years. In 1905, he formed a partnership for the practice of law with J. C. Heitsman. His law business extended into many avenues of activity. In politics, he was a Democrat. In 1904, Mr. Reynolds was elected mayor of the town of New Sharon. Some years later, Mr. Reynolds moved to Oskaloosa, where he continued the practice of law. He was there elected mayor of Oskaloosa, and during his administration, the city hall was erected. Mr. Reynolds died at Oskaloosa, Iowa, December 14, 1922.

JAMES RHINEHART studied law and practiced his profession in Guernsey, Ohio. He came to Mahaska county in May, 1854, and engaged in practicing law and farming. He was elected judge in Mahaska county and so served for eight years. He was also mayor of the city of Oskaloosa for three years. Mr. Rhinehart was born in Greene county, Pennsylvania, August 22, 1802, and died about April 1, 1879. He was of such character that he had the respect of all who knew him.

Gen. ElliotT WARRen RICE, a younger brother of Gen. Samuel A. Rice, was born in Pittsburgh, Pennsylvania, in 1835. He graduated from Franklin college, Ohio, and the law school at Albany, New York. In 1855, he became associated with his brother, Samuel A. Rice, in the practice of law in Oskaloosa, which continued until 1861. At that time, Mr. Rice joined the 7th Iowa infantry as a sergeant. He was later promoted to major, then colonel, and finally brigadier-general in 1864. He died at Sioux City, Iowa, June 22, 1887.

JAMES A. RiCE, a native son of Mahaska county, was born in Oskaloosa September 30, 1855. After attending the common schools for a number of years, he entered Oskaloosa college, where he studied two years, then completed a course at Washington and Jefferson college. He finished with the class of 1875 . In 1876 , he entered the law department of the State University of Iowa and graduated in 1877. In 1878, he was elected mayor of Oskaloosa, and was re-elected in 1879. In 1881, he was elected city 
solicitor, which office he held for four years. He was the son of Gen. Samuel A. Rice. $\mathrm{He}$ is now deceased. Mr. Rice was a Presbyterian, Mason, and a Knight Templar. He was generally interested in public affairs, and aided all deserving enterprises.

Gen. Samuel A. Rice was born in Cattaraugus county, New York, on January 27, 1828. He attended the public schools in Ohio, and worked on boats on the Ohio and Mississippi rivers. He worked his way through Mount Union college, New York, and later attended law school one year at the State University of Iowa and was admitted to the bar of Iowa. In 1851, he came to Oskaloosa. He soon was elected prosecuting attorney of Mahaska county, and rendered fine service. In 1856, he was elected attorney general of the state of Iowa, and was re-elected in 1858. He was a Republican and helped organize and form that party in Mahaska county, becoming one of its leaders. His professional career was ended by the Civil war. He entered the service and was commissioned colonel of the 33rd regiment of Towa infantry. In 1863, he was commissioned brigadier-general. As a result of his war injuries, he died July 6, 1864.

Capt. Charles P. Searle, pioneer attorney in Mahaska county, was born in Chester, Hampden county, Massachusetts, April 16, 1831. He located in Mahaska county in May, 1854. He was engaged in the mercantile business until the war, when he enlisted in 1861 in the 8th regiment, Iowa infantry, Company $H$. The splendid military service of Mr. Searle merited him the appointment of captain. In 1866, he was elected clerk of the courts in Mahaska county, and held that office for eight years, during which time he studied law and was admitted to the Iowa bar, and began the practice of his profession. Mr. Searle was also engaged in the banking business. When he first located in Mahaska county, there were no railroads within its borders. He was one of the earliest abstractors in Mahaska county. Many of the abstracts still used in the county bear certificates signed by him. Captain Searle was successful in business, acquiring a comfortable fortune from his different business activities, as well as the highest respect and esteem of his business associates. He died November 10, 1918.

Byron V. Seevers came to Mahaska county in 1853 , and romained until the time of his death. He was born in Coshocton county, Ohio, March 3, 1847. He was admitted to the bar of Iowa in 1875, and practiced in Oskaloosa for a time in partnership with John O. Malcolm. In March, 1880, he was elected mayor of Oskaloosa, and retired from the practice of law. In the fall of 1877 and again in $1879, \mathrm{Mr}$. Seevers was nominated by the Democratic party for the state legislature, but was not elected, although he 
ran far ahead of his ticket. His activity in law practice was diverted by other interests.

George W. Seevers was born in Coshocton county, Ohio, in 1843 , came to Mahaska county with his parents in 1853 , and attended the public schools and Oskaloosa college. He later went to the Ann Arbor, Michigan, law school, from which he graduated in 1864. After practicing at Indianola, associated with his fatherin-law, P. Gad Bryan, he came to Mahaska county about 1890 . Associated with him at different times were Judge William $\mathbf{H}$. Seevers, John O. Malcolm, and Leroy E. Corlett. In politics, Mr. Seevers was an influential Republican. He was a Mason. For a number of years prior to his death, he was general counsel of the Minneapolis \& St. Louis Railway, with headquarters at Minneapolis, Minnesota. In addition to an extensive legal practice, he was interested in farming and the raising of fine Jersey cattle. After a busy professional career, Mr. Seevers died at Oskaloosa, Iowa, in December, 1916.

JAMES A. SEEvers was born in Jefferson county, Virginia, March 6,1832 . He came to Iowa in 1842 , studied law with his brother, Judge William H. Seevers, and was admitted to the Iowa bar in 1853. He formed a partnership with Judge J. A. L. Crookham. In 1856, he was elected county attorney. He then formed a partnership with his brother and M. T. Williams. In politics, he was a Democrat. During the Civil war, he was captain of Company C, 15th Iowa regiment. He was in many battles, and had to resign because of wounds received. He died at the age of thirty-three on November 5,1865 , as a result of his war injuries. He was once a candidate for the legislature on the Democratic ticket, but was not successful. Mr. Seevers was a very fluent public speaker.

Judge W. H. SeEvers came from one of the proud old Southern families, being born in Shenandoah county, Virginia, April 8, 1822. He came to Oskaloosa June 22, 1844, where he resided until his death in about 1897. He was admitted to the bar and began practice in Mahaska county in 1846. During his practice, he was associated with William T. Smith, and with his brother, James A. Seevers, and for several years, with M. T. Williams. He was later associated with M. E. Cutts. In 1876, Judge Seevers was elected to the supreme bench of Iowa. Prior thereto, and in 1847, he was elected to the general assembly of Iowa, and again in 1875 , but resigned when elevated to the bench in 1876 . In 1850 and 1851 , he was county attorney, and in 1852 , he was elected district judge, where he served for four years. He served on the supreme bench of Iowa for thirteen years. He was a man of distinguished and high legal ability, and honor to the profession and to the high offices which he held. He enjoyed the respect and confidence 
of the people of all classes. All recognized his merit and ability. He was an inspiration to the members of his chosen profession.

Sen. Lewis T. Shangle was born in Mahaska county March 18, 1863. He received his education in the public schools of Mahaska county and at Penn college in Oskaloosa. He was admitted to the bar of Iowa in May, 1889. In 1890, he moved to Grand Island, Nebraska. In 1895, he returned to Mahaska county, where he began the practice of law, which continued until the time of his death. He was a Democrat, and was elected as state senator from Mahaska county in 1932 and served until his death September 2, 1935.

HOWARD H. SHerIFF was born in Iowa about 1861. He obtained his education in the public schools, and studied law in the office of Bolton \& McCoy in Oskaloosa. Thereafter, he was admitted to the bar of Iowa, and began the practice of his profession in Oskaloosa. Mr. Sheriff built up a successful law practice, and was also engaged in outside activities, including the operation of coal mines and a telephone company. He was an aggressive worker, and his energetic activities produced successful results. $\mathrm{He}$ died in Miahaska county, November 8, 1928.

William T. Smith, one of Mahaska county's foremost citizens and businessmen, was born May 23, 1824, in Fayette county, Pennsylvania. Mr. Smith was admitted to the bar of Iowa on October 18, 1847, at Burlington. He reached Oskaloosa March 10, 1848, and engaged in the practice of law with W. H. Seevers. In the fall of that year, Mr. Smith was elected prosecuting attorney for Mahaska county on the Democrat ticket. He held the office two years. About May 17, 1852, he became associated with Judge Loughridge in legal practice, and later with M. T. Williams. Smith \& Williams opened the first bank in Oskaloosa on March 1, 1855, under the name of William T. Smith \& Company. Mr. Smith was president of the Oskaloosa school board for several years, a member of the board of directors, and rendered valuable, active service to the cause of public education. As an agriculturist and land-owner, Mr. Smith took great interest in the affairs of Mahaska county generally. He was the first mayor of Oskaloosa, elected in 1853. He was also elected mayor in 1856, 1857, and again in 1872. Belonging to the minority (Democrat) party, his election reflected the confidence of his fellow townsmen. In 1870 , he was nominated by the Democrat party for congress, but was defeated in the election. During the war, he served his country at home rather than in the military forces, and for the civilian work accomplished received commendation from Governor Kirkwood. By those who knew Mr. Smith, it is said that he deserved his success, his fortune, and his friends. He died in Marion county, Iowa, December 14, 1905. 
Henry Temple, a young lawyer of Mahaska county, married a Mahaska county girl on January 18,1846 . He was present when the first court met in Oskaloosa. About a year later, he moved from Oskaloosa to Atlantic, Iowa, where he practiced law. We have no further information of him.

George C. True was born at Eddyville, Iowa, September 5, 1871. He received his education at the State University of Iowa. After that he was admitted to the bar of Iowa, and practiced with John o. Malcolm in Mahaska county for a number of years, before moving to Davenport, Iowa, where he died May 21, 1945. Mr. True was a Republican, and served as postmaster in Oskaloosa for a number of years. He was a Mason and very active in $K$. of $P$. lodge, which organization he served as one of the state officers for a time. He was active in Red Cross work in Mahaska county. During his practice, he was attorney for the M. \& St. L. Railway, with headquarters in Minneapolis, Minnesota, being associated with George W. Seevers.

DAVID C. WAGgONer was born in Oskaloosa, November 16, 1856, and attended Oskaloosa high school and Penn college. He began the study of law with Major John F. Lacey, and was admitted to the bar in 1880 . Politically a Democrat, he continued his practice in Oskaloosa until his death on January 17, 1925. For a time, he was associated with L. T. Shangle.

A. J. Walsmith was borm in Northville, La Salle county, Illinois. He attended the public schools of Illinois, and the high school at Sanborn, Iowa, and later the State University of Iowa. He was admitted to the bar of Iowa in 1894 . He was county attorney of O'Brien county, Iowa, 1899-1903, inclusive, and city attorney of Sheldon, Iowa, 1906-1908. He came to Mahaska county in 1919, and practiced law in Oskaloosa until April 1, 1944, when he retired, and with his wife, went to Connecticut to live near their children. Mr. Walsmith was a Republican and very active in Masonry since 1902. He was past master and junior grand warden in Iowa. He was an ardent student of the life, character, and works of Abraham Lincoln, and considered an authority in that field. While practicing law in Oskaloosa, he had some association with the firm of McCoy \& McCoy, although he was not a member of the firm.

E. H. WARING was a lawyer in Mahaska county about 1882 , and was court reporter for Judge J. Kelly Johnson. He was also associated with the firm of Bolton \& McCoy, and also with Hillis \& Hole in New Sharon. Mr. Waring has been dead for a number of years. 
T. R. WILkIE was born at Luana, Iowa, May 8, 1875. He acquired his education in the public schools, later studied law, and was admitted to practice law in the state of Iowa. He came to Oskaloosa and entered the practice of his profession about 1916, and continued until his death on September 24, 1933. During a part of that time, he was associated with S. V. Reynolds.

John Cambria Williams was a Democrat, but his popularity caused him to be elected to office several times in a Republican stronghold. He was born in Naperville, Illinois, in 1851. Mr. Williams attended the common schools in his home community in Illinois. In 1872, he came to Oskaloosa, and in 1877 graduated from Penn college. He taught school and was elected county superintendent in 1877, and acted as such for one term. In 1880, he entered the law office of Bolton \& McCoy, where he studied for two years. He was admitted to the bar in 1882 . He established the first cheese factory in Mahaska county, but discontinued that work after beginning the practice of law. He was associated in his legal practice with L. C. Blanchard and later with W. R. Nelson. Mr. Williams was a member of the Episcopal church, and belonged to the Masons, the Elks, and the Knights of Pythias. He served as city solicitor for three terms and two terms as mayor of Oskaloosa. He cooperated with men in Oskaloosa who were interested in the citizens' welfare and general improvement. $\mathrm{He}$ took a great pride in civic improvement. He moved to Florida in about 1912, and died there some years later.

MicajaH T. WILLAams was one of the pioneers of Mahaska county and served as one of the commissioners for the organization of the county. Mr. Williams was born in Butler county, Ohio, May 29, 1820. When he was a mere child, his parents moved to Terre Haute, Indiana. He attended Wabash college at Crawfordsville, Indiana. He was admitted to practice law in Ohio in 1842. On the second of May following, he started for Iowa on horseback. In 1843, Mr. Williams came to Mahaska county. He was appointed clerk at the first term of the district court in Mahaska county and served until 1854. In August of that year, he was elected to the state legislature, and served in both the Fifth and the Ninth General Assemblies. He formed a partnership with William T. Smith for the practice of law. These gentlemen, being progressive, opened the first banking house in Mahaska county on March 1,1855 , and continued for nearly three years, when Mr. Williams retired. He was later associated with William T. Seevers and Liston McMillen in the practice of law. In 1850, Mr. Williams became a member of the Tri-Luminar Lodge, No. 18, A. F. and A. M., and subsequently a member of Hiram Chapter No. 6, R. A. M., and also a Knight Templar. He was a vestryman of St. James Episcopal church. Mr. Williams died 
at Oskaloosa on January 15, 1884. Perhaps no citizen of Mahaska county was more greatly missed and more greatly mourned than Mr. Williams. He was a friend to the young and gave courage and help to many young men. He was a careful attorney and a splendid man in every way.

ARCH WooDrow, born July 29, 1896, in Mount Pleasant, Iowa. He studied in the public schools and law college, and was admitted to the bar of Iowa. He was court reporter for Judge J. G. Patterson, of the sixth judicial district, for a number of years. Failing health required his retirement, and he died at Oskaloosa, Iowa, February 26, 1948.

George H. Woodson, a colored lawyer, was very active in the practice of law in Mahaska county during the time the coal mines were in full operation. He had quite an extensive practice in Mahaska and Monroe counties. He later moved to Des Moines, where he died a number of years ago.

There are a few names of lawyers who for a short period, in years gone by, practiced in Oskaloosa, and about whom we are unable to give detailed information. They are:

WILLARD CARVER, who, after practicing law for a number of years, became a chiropractor and moved away. He was a member of the firm of Carver \& Wooster.

JAMES F. Cook, was in Mahaska county for only a short time and then moved away.

B. Coultar for a short time was associated with J. A. Seevers and then moved away from Mahaska county.

C. W. FISHER, after a short time in practice in Mahaska county, died about 1916.

Z. W. Fisher for a short time was associated with Judge J. A. L. Crookham. He is evidently long since deceased.

WILLIAM KENNEDY was practicing in Oskaloosa in 1876. He died August 10, 1925, in Marion county, Iowa.

PHILLIP MYers was practicing law in Oskaloosa in 1862, but did not continue for a long period of time. He is now deceased.

JOHN W. SARvis was practicing in Oskaloosa in 1911, but continued only for a short time, and then moved away.

W. E. SHEPHERD was engaged in the practice of law in Mahaska county and was associated with John F. Lacey for only a short time. 
T. M. Simonton practiced law in Mahaska county from about 1902 to 1912, when he discontinued his practice and took up the pursuit of agriculture. $\mathrm{He}$ is still living.

Samuel Thompson was one of the early county judges of Mahaska county who gave some attention to the practice of law and was the first county surveyor, devoting much of his time to that line of work. He is now deceased.

JUDGE JOHN WhITE was elected judge of probate in Mahaska county in 1846, and died in 1853 as the result of the amputation of a broken leg.

ALFRed Wooster practiced law for a time in Mahaska county as a member of the firm of Carver \& Wooster, then discontinued practice and moved away.

HENRY L. Thatcher, one of the early lawyers of Mahaska county, was engaged in the practice of law and other business at Oskaloosa for a good many years. He is now deceased.

\section{SeCtion II}

The following lawyers comprise the Mahaska County Bar at this time, as they are now practicing law here.

HowaRD T. BEACH was born in Oskaloosa, Iowa, January 25, 1900. He attended the public schools in Mahaska county and the State University of Iowa. In June, 1936, he was admitted to the bar ofIowa, and began the practice of law in Oskaloosa. Following the death of Capt. W. H. Keeting in 1942, Mr. Beach took over Mr. Keating's practice and abstract work, and has since had the abstract business associated with his law practice. Mr. Beach is a Mason, a B. P. O. E., a member of the American Legion, a reserve officer in the United States army, and a member of the American Title association and the Iowa Title association. $\mathrm{He}$ served with the U. S. army in 1918 and also in World War II from 1942 to 1945 . He enjoys a good business.

THOMAS JAMES BRAY, one of the senior members of the present bar, was born at North Danville, Vermont, August 31, 1877. Mr. Bray received his education through the public schools in Vermont and at Grinnell, Iowa. He began the practice of law in Mahaska county in 1916, after having been admitted to the bar of Iowa in 1904. Prior to beginning his law practice, he served as court reporter, from 1899 to 1905 . Within the last two years, Mr. Bray became the senior member of the firm of Bray, Carson \& McCoy. Mr. Bray's practice has been extensive and successful. His outside interests include agriculture and fine stock raising. 
L. R. CARSON received his legal education at the University of Iowa, and was admitted to the Iowa bar on June 15, 1932 . He began the practice of law in Mahaska county in 1934 . He was born at What Cheer, Keokuk county, Iowa, August 26, 1904. He recently became associated with the firm of Bray, Carson \& MeCoy. In politics, he is a Republican. He served as county attorney of Mahaska county in 1943; and after an absence in the United States army from June 15, 1943, to 1946, he was again elected county attorney, and is still serving as such, and has the nomination for re-election in 1948, which is assured. Mr. Carson is a Mason, an Eagle, an Elk, and a member of the P. A. D. legal fraternity. From June 15, 1943, to May, 1946, he served in the United States army as J. A. G. D. first lieutenant. Mr. Carson has made a good record in his law practice as well as in his military service.

LEROY EVERTON CORLETT was born in Clayton county, Iowa, March 18, 1875. He attended the public schools, the National Normal university, Lebanon, Ohio, and Iowa College of Law, then the law department of Drake university, graduating May 17, 1901, with LL. B. degree. He was admitted to the bar of Iowa May 15, 1901. In 1904, he began the practice of his profession at Oskaloosa, Iowa. He served as clerk of the district court for six years, beginning January 7, 1907. Later he entered into partnership with George W. Seevers, under firm name of Seevers \& Corlett, which continued until the death of Mr. Seevers. During World War I, Mr. Corlett served as a volunteer Y. M. C. A. secretary with the U. S. army in France. During World War II, he was county chairman for war bond sales. He was mayor of Oskaloosa for two years, beginning April 2, 1923, and city solicitor from August, 1943, to April, 1947. He is a Republican, a Pres-. byterian, Mason, and Kiwanian. One of his chief outside interests centers in the Boy Scouts of America. He is now president of the southern Iowa area council of that organization. Mr. Corlett enjoys golf, fishing, and travel. Although engaged in outside activities, he always gives first consideration to his legal practice. He is a member of the county, state and American bar associations.

Joe C. Crookham was born in Mahaska county June 2, 1906. He attended the public schools and the State University of Iowa, from 1933 to 1935 . He was admitted to the Iowa bar in June, 1935. Mr. Crookham served in the army from May, 1943, to 1946, most of which time was in Canada and Alaska on the highway project. He entered the law practice in Oskaloosa in September, 1946, and is still so engaged. In 1948, he was appointed city assessor. 
Lake M. CrookhaM came from pioneer stock and was born in Oskaloosa, Mahaska county, Iowa, on August 24, 1906. In addition to attending the public schools, he attended Penn college one year (1924-1925) and the State University of Iowa, where he received his B. A. degree in 1928. From 1928 to 1931 he attended the State University law school. He participated in the university's world cruise from 1926 to 1929 . In 1931, he was admitted to the Iowa bar, and has practiced law in Mahaska county since that time. In 1946, he became associated with Joe C. Crookham in the law practice. Politically, Mr. Crookham is a Republican. As such, he was elected and served as mayor of Oskaloosa from 1939 to 1946 . He is a member of the Delta Upsilon social fraternity and the law fraternity, P. A. D. He is also a member of the Masonic, Elk, and Eagle lodges of Oskaloosa. Mr. Crookham enjoys outdoor sports, including hunting and fishing. His many business interests lead him into a varied and extensive practice.

T.HERESA DAvis has the distinction of being the first woman lawyer to become a member of the Mahaska county bar. She was born in Oskaloosa on July 30, 1909, and attended Oskaloosa high school, Penn college, and Drake university. She was admitted to the bar of Iowa in June, 1932, and began the practice of law in Mahaska county in 1934, associated with H. S. Life, now the firm of Life \& Davis. In politics, she is a Republican and served as vice-chairman of the Mahaska county Republican organization for several years. She is a member of Delta Gamma sorority, the National Association of Women Lawyers, state and national bar, American Legion, and Amvets. Miss Davis greatly enjoys golf. From September 1, 1942, to March 30, 1946, she was a WAAC private and first lieutenant, and was also a WAC, AUS major. Miss Davis enjoys the consideration, cooperation, and respect of the entire bar.

JAMes L. DevitT was born in Oskaloosa June 16, 1904. During 1920-1921 he attended Culver military academy. He graduated from the Oskaloosa high school in 1923, and from the State University of Iowa in 1927 with an A. B. degree. In 1929, he received from the state university his LL. B. degree. He immediately thereafter began practice of law in Oskaloosa, associated with his father, James A. Devitt. He served as county attorney, after serving as city solicitor, of Oskaloosa.

HAROLD J. FLECK was born at Sully, Iowa, November 11, 1896. He attended Newton high school and Grinnell college, and received his LL. B. degree from Harvard law school in 1924, and was admitted to the Iowa bar. Mr. Fleck began practice of law in Oskaloosa in 1932. He is now the senior member of the firm, Fleck \& Jones. In politics, he is a Democrat, and at this time 
is a candidate for attorney general of the state of Iowa. He served as county attorney in 1935 and 1936 . He also served as city solicitor of Oskaloosa. Mr. Fleck served in U. S. N. R. F. during World War I. He is interested in manufacturing, aside from a good law practice. Mr. Fleck is an Elk, Eagle, Mason, and a member of the American Legion.

Ned P. GILberT was born at Valley Junction, Iowa, May 30, 1915. He attended college at Washburn university and college of law and Northwestern university law school. Before coming to Mahaska county in December, 1942, he had practiced law in Kansas, where he was admitted to the bar in 1939 . He practiced from 1939 to 1942 in Chicago, Illinois. Soon after coming to Mahaska county, he became associated with J. C. Eichhorn, and was with him until the death of Mr. Eichhorn, except for the time Mr. Gilbert served in the army during World War II. The firm of Eichhorn \& Gilbert was in existence 1943-1946. In politics Mr. Gilbert is an active Republican. He belongs to the American Legion, Masons, Elks, Eagles, and the Kiwanis club. He is a director of the chamber of commerce. In sports, he enjoys fishing, hunting, and baseball. During 1944, 1945, and 1946, he served as first lieutenant in the United States marine corps, fourteen months of which were overseas in combat service. Mr. Gilbert is a member of the Mahaska county, Iowa, American, and Chicago bar associations. He is active in all public interests and enjoys an active legal practice.

IRving C. JoHnson, a son of Judge J. Kelly Johnson, one of the early judges in Mahaska county, was born at Oskaloosa June 1, 1872. He obtained his education in the Oskaloosa public schools, Penn college, and Haverford college, Haverford, Pennsylvania. Mr. Johnson was admitted to the bar of Iowa in May, 1895, and has practiced law in Mahaska county since that time, and is still active as the senior member of the firm of Johnson \& Sproatt. He and John S. Sproatt became associated together in 1946. A few years ago, Mr. Johnson was appointed and successfully served as referee in bankruptcy. He is a Republican in politics, and a member of the Rotary club. Prior to his association with $\mathrm{Mr}$. Sproatt, as well as at the present time, Mr. Johnson enjoyed a very fine practice with an excellent clientele.

EARL R. JONES was born in Mahaska county, July 1, 1908. Mr. Jones secured his education in the public schools of Oskaloosa, Penn college, and Drake university law school. He was admitted to the bar of Iowa June 8, 1933, and began practicing law in Oskaloosa September 1 of the same year. During World War II, he served in the United States army air forces overseas, in the Pacific area. After returning from military service, Mr. Jones became 
associated with Harold J. Fleck, as Fleck \& Jones; they are still practicing law in Oskaloosa. Politically, Mr. Jones is an active Republican. He is a member of the Sigma Alpha Epsilon fraternity. He is an active member of his firm, aggresively interested in the welfare and interests of his clients.

How ARD S. LIFE was born in Ohio July 18, 1893. Mr. Life was as a youth a careful student of his surroundings, a searcher for facts and information; and in that manner, he obtained a liberal education. He was admitted to the bar of Iowa on June 7, 1928, and immediately thereafter began the practice of his profession in Oskaloosa, where he still enjoys an extensive legal business. For the last few years, and at the present time, Mr. Life is associated with Theresa Davis, under the firm name of Life \& Davis. Mr. Life enjoys membership in the Masonic, Knights of Pythias, and Oddfellow lodges. He has served in the Iowa national guard. His interests are extensive and varied. At the present time, and for a few years back, he has been intensely interested in aviation.

HUGH BEN MCCoY was born in Des Moines, Iowa, May 25, 1918. $\mathrm{He}$ attended the State University of Iowa, from which he was graduated, and admitted to the bar of Iowa in 1941. Immediately thereafter, he began practice of his profession at Oskaloosa, Iowa, and became a member of the firm of Bray, Carson \& McCoy. His legal practice was interrupted by World War II, in which he served in the army air corps, 1942-1946. He is a Republican in politics and has been county chairman of that organization since 1946. Mr. McCoy is also a member of the V. F. W., American Legion, Elks Lodge, and Phi Delta Phi. Mr. McCoy is a young man with a promising future.

ARLO W. PALMER received his education at Grinnell college, Grinnell, Iowa, University of Wisconsin, and the State University of Iowa, and was admitted to the bar of Iowa in 1922 . He began the practice of law in Mahaska county in 1924, associated with William M. Spencer, as the firm of Palmer \& Spencer. Mr. Palmer served as county attorney of Mahaska county from 1931 to 1935 . $\mathrm{He}$ is a Mason, Eastern Star, and Knight of Pythias, and belongs to the Kiwanis club and Methodist church. He was in the United States army during World War I from April 5, 1915, to July 18, 1919 , and served overseas. 1940-1947 he served as a member of the Mahaska county selective service board. 1939-1948 he was a member of the Mahaska county hospital board. 1946-1948 he was a trustee of Kletzing college of Oskaloosa, Iowa. Mr. Palmer was born at Malcom, Iowa, December 28, 1895. His firm is considered dependable, obtaining very creditable results.

JUdGe JAMES G. PATTERson was born in Jasper county, Iowa, Auguist 6,1871 . He attended Oskaloosa college in 1894. In 1899, he re- 
ceived his $\mathrm{Ph}$. D. degree from the University of Iowa; and in 1901, his LL. B. degree. He began his legal practice in Oskaloosia in 1901. He was elected county attorney and served as such, 19091913, and as city solicitor of Oskaloosa, 1925-1926. He was elected judge of the district court in 1928, and is still serving as such in a very satisfactory way.

EDWARD A. SchmidT began the practice of law in Mahaska county before World War I. He served with the military forces during that war and returned to Oskaloosa, where he is still practicing his profession.

ROBERT J. SPAYDE was admitted to the bar of Iowa on June 29, 1943, after receiving public school education at Sioux City, Iowa, and graduating from the State University of Iowa. Mr. Spayde was born at Sioux City, Iowa, October 18, 1917. He began the practice of law at Oskaloosa in Mahaska county April 15, 1946, associated with Charles A. Williams, Jr. In politics, Mr. Spayde is a Republican, serving as ward committeeman in Oskaloosa in 1948. He was appointed city attorney in 1947, and is still serving as such. His fraternity connections are Phi Delta Theta and Phi Delta Phi. He belongs to the American Legion and Elks lodge. $\mathrm{He}$ is also a member of and secretary of the Rotary club, and is a member and usher of the Central Methodist church. During World War II, Mr. Spayde served with the army engineers from July 28, 1943, to March 7, 1946, two years of which were in the Pacific area. When discharged, he was a master sergeant. He has a promising future.

William M. Spencer was born in Madison county, Iowa, May 7, 1903. He attended high school at Earlham, Iowa, got his B. S. degree at Coe college, Cedar Rapids, in 1927, and his J. D. degree, at the State University of Iowa college of law, in 1931. In June of that year he was admitted to the bar of Iowa. He began the practice of law in Mahaska county and became a member of the Mahaska county bar November 1,1931 . In politics, he is a Republican. In 1935 and 1936, he was city solicitor for Oskaloosa, and from 1939 to 1942 was county attorney of Mahaska county. In 1948, he became a member of the city board of review. Mr. Spencer is a member of the K. of P. lodge, Oskaloosa, and of the Delta Theta Phi legal fraternity. The firm of Palmer \& Spencer has existed for a number of years, and is still enjoying a growing practice.

JoHN S. SproatT, who came to Mahaska county on April 15, 1946 , became associated in the practice of law with Irving C. Johnson, under the firm name of Johnson \& Sproatt. This firm enjoys an extensive and successful legal practice. Mr. Sproatt was born 
at Iowa City, Iowa, May 13, 1917, and attended the public schools there and also the State University of Iowa. He was admitted to the bar of Iowa in June, 1942. In politics, he is a Democrat. Mr. Sproatt is a member of the American Legion (Adj.) and Elks, and also the Beta Theta Pi, Phi Delta Phi, and Phi Beta Kappa fraternities. During World War II, Mr. Sproatt served in the United States army from May, 1942, to April, 1946. He is now commander of the American Legion post at Oskaloosa.

Byron Ver Ploeg was born in Oskaloosa, March 28, 1909. He attended grade and high schools in Oskaloosa, and received his A. B. degree from Penn college and his LL. B. degree from Drake university, Des Moines. He was admitted to the bar in June, 1934, and at once began practice of his profession at Oskaloosa, Iowa, associated with his father, C. Ver Ploeg, under the firm name of Ver Ploeg \& Ver Ploeg. $\mathrm{He}$ is a democrat and served as precinct committeeman, 1934-1942. He was appointed city solicitor of Oskaloosa in 1936-1938. He is a member of the $\mathrm{K}$. of P. lodge. Beginning in September, 1947, he became an instructor in Drake university law school. In 1944-1945, he spent a year and a half in Wyoming as project attorney with the war re-location authority in a Japanese re-location center, where his work was well done.

CORNelius Ver Ploeg, one of our older lawyers, who is still practicing, was born in Pella, Iowa, October 10, 1871. He obtained his education in the country schools, at Normal college, Dixon, Illinois, and at Highland Park college, Des Moines, Iowa. He was admitted to the bar of Iowa in January, 1900. The following year he came to Oskaloosa and began the practice of his profession, and has actively engaged in the law business ever since. $\mathrm{He}$ has associated with him his son, Byron Ver Ploeg, under the firm name of Ver Ploeg \& Ver Ploeg. Mr. Ver Ploeg was city solicitor for Oskaloosa, 1924-1926, 1928-1930. He is a member of the Knights of Pythias, and has varied outside interests. In politics, he is a Democrat. $\mathrm{He}$ is still actively engaged in the practice of his profession.

Kryne Ver PloEg was born in Marion county, Iowa, October 28, 1880. After attending the schools of his county, he entered Drake University law school, from which he was graduated, and admitted to the bar of Iowa June, 1910. He soon located in Oskaloosa, and began the practice of law. After a few years, he engaged in other business, in which he is still active in Mahaska county. Mr. Ver Ploeg enjoys sports, especially hunting and golf. 
Charles A. Williams, Jr. The subject of this sketch was born February 4, 1906, at Lucas, Iowa. He received his education at the Oskaloosa public schools, Penn college (A. B., 1928), and Harvard University (LL. B., 1931). Mr. Williams was admitted to the bar of Iowa in 1931, and at that time began his practice in Oskaloosa. For about the last two years, Robert J. Spayde has been associated with Mr. Williams. In politics, Mr. Williams is an influential Republican, and served as G. O. P. county chairman, 1940 to 1946. Mr. Williams is a member of the Elks lodge, the Kiwanis club, and of the Congregational church of Oskaloosa. He has many interests in connection with his legal practice.

ROSCOE J. WOODARD was born in Lucas county, Iowa, in 1883. He received his A. B. degree from Cornell college, Mount Vernon, Iowa, in 1907, and his law degree from the State University of Iowa in 1911, at which time he was admitted to the bar of Iowa. In 1912, he moved to Mahaska county and began the practice of law. He was county attorney of Mahaska county, 1923-1926. He is a Republican in politics, and belongs to the Phi Alpha Delta fraternity. Mr. Woodard retired from law practice a few years ago, but still lives in Mahaska county, and is engaged in farming.

In closing this sketch of the Mahaska County Bar, I feel that one factor, which has helped to give this bar its high character and standing, should be mentioned. That is the fine and able men who have served as judges in the Sixth judicial district, of which Mahaska county is a part. These judges have been and are men of fine legal ability, intent upon the administration of justice as provided by law. Their fairness in the conduct of their duties has been an inspiration and guide to all right-minded lawyers appearing before them. To all these judges, who have and do so uphold the fine traditions of the law, we are indebted and are grateful.

Oskaloosa, Iowa, August 1, 1948. 
Copyright of Annals of Iowa is the property of State of Iowa, by \& through the State Historical Society of Iowa and its content may not be copied or emailed to multiple sites or posted to a listserv without the copyright holder's express written permission. However, users may print, download, or email articles for individual use. 